\title{
New Insights on the Morphology of the Philippine Endemic Ficus pseudopalma Blanco
}

\author{
Victor B. Amoroso ${ }^{* 1}$, Cristine Mea A. Aser ${ }^{1}$, Annabelle P. Villalobos ${ }^{2}$, Rainear A. Mendez ${ }^{1}$, \\ Domingo P. Lodevico ${ }^{1}$, Gina B. Barbosa ${ }^{1}$ \\ ${ }^{1}$ Central Mindanao University, Maramag 8714, Bukidnon, Philippines \\ 2Johnson \& Johnson, PA 19044, United States
}

\section{Article history:}

Submission October 2021

Revised October 2021

Accepted November 2021

*Corresponding author:

E-mail: f.victor.amo-

roso@cmu.edu.ph

\begin{abstract}
Ficus pseudopalma Blanco is an endemic Philippine plant with many medicinal uses and an ethnobotanically as a green vegetable or side dish. With these several economic uses of the plant, there is a need to investigate the morpho-anatomy and development of the species. Seeds of F. pseudopalma were collected in Mt. Hamiguitan Range Wildlife Sanctuary and grown in the Central Mindanao University Garden to monitor the growth and development of the species. Unique morpho-anatomical features include sparingly branched glabrous stem with spirally-arranged reddish terminal leaves crowded at the apical part, paired persistent stipules, anomocytic stomata, without glandular hairs and with leptocentric bundles in the petiole. The inflorescence is likewise unique, being enclosed to form a syconium (fig) which occurs in pairs and axillary. The flowers are imperfect with the staminate flowers situated the osteole while the pistillate flowers are at the syconia's interior and pollinated by agaonid wasps. The seeds germinated after four days of sowing, and syconia were formed after 365 days exhibiting several stages of development. These morphological and developmental characteristics are important in mass propagating this endemic plant for its medicinal and food uses.
\end{abstract}

Keywords: Anatomy, Development, Seed formation, Syconium

\section{Introduction}

Ficus is a pantropical genus belonging to Moraceae family and it is one of the largest genus with 800 species worldwide and 367 currently recognized in Malesian region [1]. Ficus is distinguished by its unique closed inflorescence called fig (syconium) dusted with white lenticels [2]. The syconium has a single and tight orifice where the pollinator wasps penetrate for fertilization [1].

One of the species of Ficus is F. pseudopalma Blanco. It is commonly known as "Philippine Fig", "dracaena fig" and "palm-leaf fig" and locally known as "niyog-niyogan" and "lubi-lubi". The species is an ornamental plant that is endemic to the Philippines and reported only in Luzon, Philippines [1]. It is an erect, glabrous and unbranched shrub growing to a height of 5 meters with leaves crowded at tips of stem giving the appearance of a small palm [3]. As food plant, young leaves of $F$. pseudopalma are cooked as vegetables and as side dish or as egg dish. Its leaves are also potential flavouring in the preparation of enriched noodles or cooked on top of steaming rice, then garnished with citrus fruit [4]. As medicinal plant, leaf decoction of F. pseudopalma is used for the treatment of hypertension, diabetes, kidney stones, and high cholesterol [5, 6]. It was reported to have an anti-oxidant activity containing terpenoids and sterols [7, 8, 9].

A number of species of Ficus have been studied morpho-anatomically such as $F$. pedunculosa, $F$. erecta, F. benjamina, F. altissima, F. caulocarpa, F. subpisocarpa, F. nervosa, F. pumila, $F$. punctata, F. variegata and F. microcarpa [1] while other species are poorly described and

\section{How to cite:}

Amoroso VB, Aser CMA, Villalobos AP, Mendez RA, Lodevico DP, Barbosa GB (2022) New Insights on the Morphology of the Philippine Endemic Ficus pseudopalma Blanco. Journal of Tropical Life Science 12 (1): 83 - 89. doi: 10.11594/jtls.12.01.08. 
understood [10]. One of these poorly described species is F. pseudopalma. Considering the food and health benefits derived from $F$. pseudopalma, its morpho-anatomy, development and propagation have not been investigated. Being endemic and with several economic uses, this study elucidates the morphology and anatomy of F. pseudopalma and its development.

\section{Material and Methods}

A gratuitous permit was obtained from the Department of Environment and Natural Resources, XI (DENR XI) to collect plants of Ficus pseudopalma in tropical lowland forest in Mt. Hamiguitan Range Wildlife Sanctuary in San Isidro, Davao Oriental, Philippines. Seeds of these collected specimens of Ficus were sown in petri dishes with wet tissue paper for germination. At 2-3 leaf stage, seedlings were transplanted to smaller pots and later outplanted in the garden of Central Mindanao University (CMU), Bukidnon, Philippines, and used to describe the morphology and anatomy in monitoring its development. Free-hand sections and clearing of leaves were done on the vegetative and reproductive organs at the Natural Science Research Center of CMU.

\section{Results and Discussion \\ Detailed gross morphology of F. pseudopalma Blanco (Figure 1)}

Sparingly branched small tree up to $172 \mathrm{~m}$ tall. Stems glabrous, $0.6-1.0 \mathrm{~cm}$ thick, white, leaf scars distinct in old stems, bark flaking off. Leaves spirally-arranged, more or less tufted; lamina sagittate-pandurate, $30-37$ by 7-8 cm, coriaceous, apex narrowly acuminate, base attenuate, margin coarsely dentate; both surfaces glabrous with cystoliths, smooth, upper surface dark green and

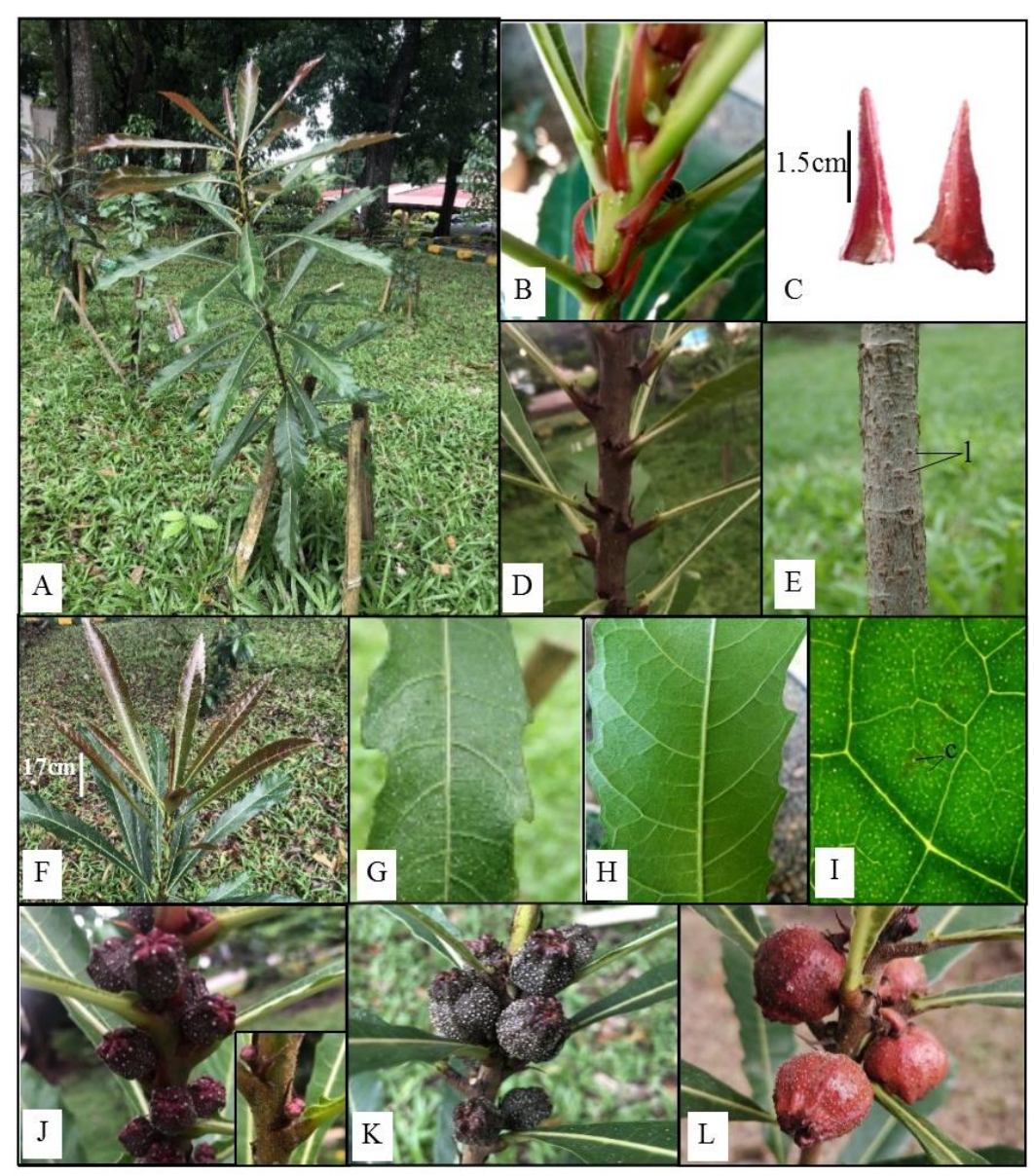

Figure 1. Gross morphology of F. pseudopalma. A. Habit; B-D. Reddish to brown persistent stipules; E. Stem with abundance of large lenticels (l); F. Spirally-arranged reddish terminal leaves; G-H Upper and lower surface of lamina; I. Very abundant cystoliths (c) in the undersurface of lamina; J-K. Young crowded dark brown paired syconia with distinct white lenticels and white hairs (inset in J); L. Mature reddish pedunculate syconia. 
shiny; lateral veins 20-24 pairs, most of them furcate far from the margin, the lower ones departing the midrib at right angles, tertiary veins largely scalariform; petiole 1-1.3 cm long, glabrous; stipules in pairs, persistent or subpersistent, deltoid, semi-amplexicaul but majority of the Ficus species have fully amplexicaul stipules [1], 1.4-1.8 $\mathrm{cm}$ by $1.3 \mathrm{~cm}$ wide, red when young turning dark brown when mature, glabrous and persistent. Syconium axillary in pairs, $1-16$ by $1-1.4 \mathrm{~cm}$ with a peduncle $0.5-0.7 \mathrm{~cm}$ long, receptacle oblong to ellipsoid with longitudinal ridges, white trichomes present when young disappearing when old, white lenticels prominent, dark becoming yellowish to reddish at maturity, apex slightly protracted, ostiole 4-8 mm diameter, surrounded by erect apical bracts; staminate flowers are situated at the upper end of syconium just below the ostiole; pistillate flowers pedicellate with long and short styles, numerous at the interior of syconium; seeds achene, 1-9 by 1-8 mm, compressed to sub-globose to oblong. The above detailed description was based on plants of F. pseudopalma grown from seeds. Authors also described $F$. pseudopalma but their descriptions on the vegetative and reproductive organs were incomplete $[3,11]$.

\section{Anatomy of the Leaf}

Transections of the petiole showed the irregular-oblong shaped with flattened adaxial side without glandular trichomes. However, F. carica L. has circular shape and with glandular trichomes [12]. Some species of Ficus like F. virens A., F. krishnae C. and F. hispida have unicellular nonglandular trichomes [14]. The single layered epidermis in $F$. pseudopalma is immediately

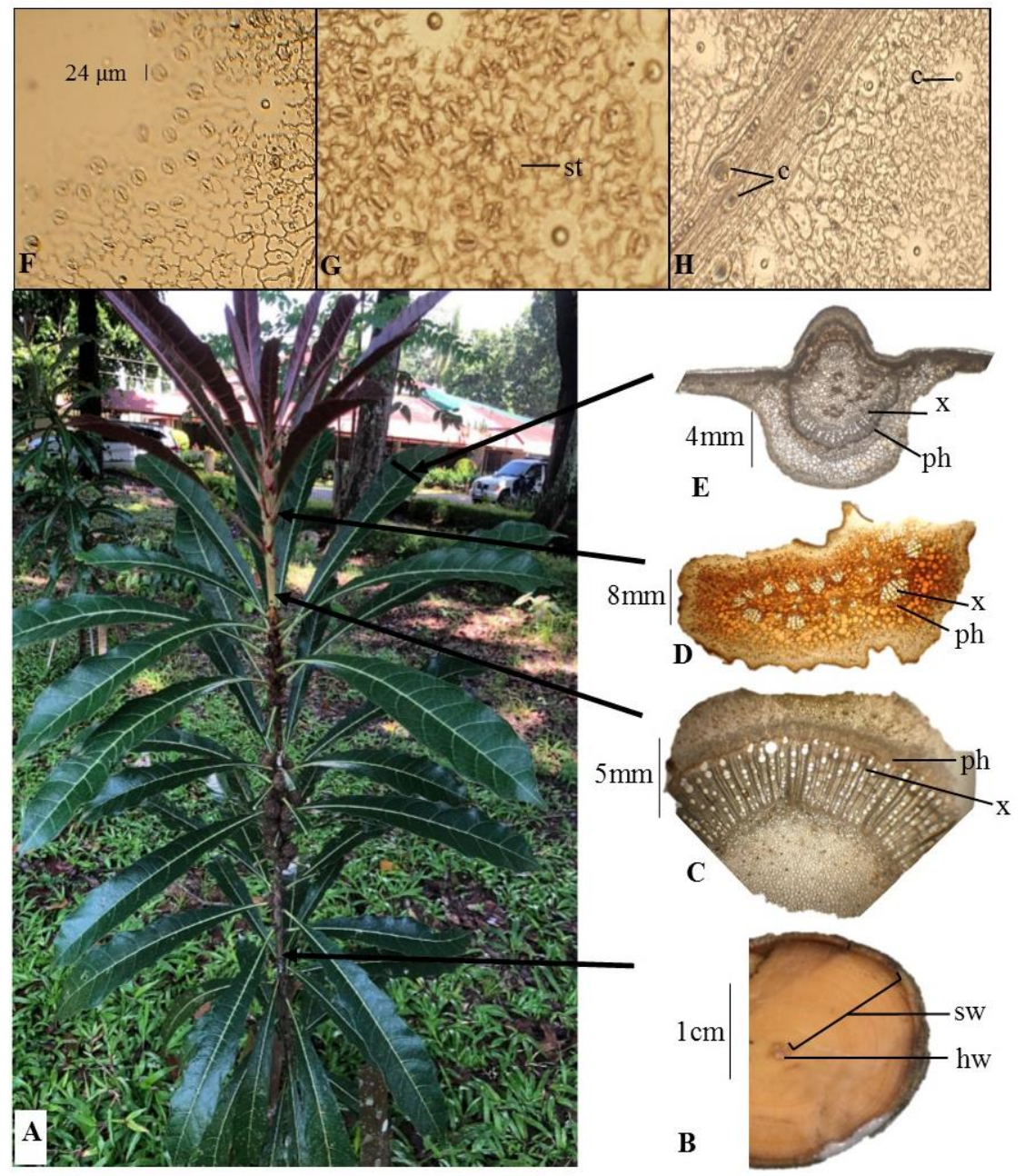

Figure 2. Anatomy of F. pseudopalma. A. Habit showing mature and young edible apical leaves; B-E Transections of stems and leaf; B. old stem (sw-sapwood, hw-hardwood); C. Young stem (ph-phloem, xxylem); D. Petiole with vascular dissected bundles (dictyostele); E. Midrib; F-H. Surface view of lamina showing anomocytic stomata (st) and cystoliths (c) 
followed inwardly by several layers of small sclerenchymatous and 2-6 layers of larger cells of parenchymatous cortical tissues. The vascular bundles are dissected (dictyostele) with the xylem tissue more prominent than the phloem tissue. Few leptocentric bundles were observed at the innermost portion of the midrib. These leptocentric bundles were also documented in F. carica [12]. The lamina at the midrib portion in transection has smooth rounded abaxial side and narrow protruding and prominent adaxial side. The mesophyll is differentiated and composed of spongy and palisade layers of cells. The cystoliths are distinct in both upper and lower surface of leaves, however, these are more abundant in the lower surface. Though trichomes are absent in F. pseudopalma, these were observed in F. carica [12]. The bundle sheath is absent and instead the phloem is well-developed. The xylem tissue forms a ring surrounding the parenchymatous innermost tissue. The surface view of the adaxial lamina exhibits sinuous walls of the ordinary epidermal cells with anomocytic scattered stomata (Figure 2F-H).

\section{Anatomy of the stem}

Transection of the young stem shows a circular outline with epidermis and cortex composed mainly of parenchyma cells. The stele is ectophloic, with the vascular tissues forming a ring and collateral. The thin phloem tissue surrounds the thicker xylem tissue radiating inward with prominent tracheary elements. The innermost tissue of the young stem is the pith composed of parenchyma cells (Figure 2C).

An old stem has undergone secondary growth characterized by the formation of secondary tissues. The epidermis of the young stem is replaced by the developing periderm, which is part of the bark. The thinner bark constitutes the outer layer of an old stem and the massive portion is the wood which is mainly composed of the secondary xylem. The primary xylem and pith are no longer observable at this stage. Later the wood differentiates as sapwood and heartwood. The sapwood occupies the outermost and bulky part of the wood, which conducts water and mineral salts, and slowly the innermost part of the sapwood becomes darker to form the heartwood (Figure 2B).

\section{Development of F. pseudopalma from seed to mature plant}

The seeds were secured from matured syconia of F. pseudopalma and were carefully removed from the protective receptacle of the syconium. The seeds were individually soaked in wetted tissue paper in a plastic container and securely covered. Without disturbing the sown seeds, after 4 days of sowing, they germinated by the emergence of radicle. Antropous radicles were observed in many seeds (Figure 3A). The embryonic stem and leaves were observed after 7 days of sowing. The embryonic shoots appear yellowish green (Figure 3B).

After 14 days of seed germination, a more developed pair of rounded leaves, a dark green leafy shoot and a longer stem were observed (Figure 3C). The seedlings were transplanted into smaller pots and covered with a cellophane during night time and removed during day time for 30 days.

After 71 days, the plants developed four leaves and dark red paired stipules with apical bud. Upper leaves of the plant are undulate and bigger while the lower leaves are rounded and smaller (Figure 3D). After 78 days, the margin of upper leaves become dentate, while the lower leaves margin are undulate and stipules becoming bigger and deltoid in shape (Figure 3E).

All plants were nurtured in greenhouse condition and later transplanted into bigger pots after 124 days. The transplanted plants produced bigger leaves with dentate margin and young reddish leaves found in the upper part of the stem (Figure $3 F$ ). In this stage, abundant lenticels were observed in the upper part of mature leaves.

Eventually plants were outplanted in field condition after 235 days. The outplanted plants grown in open areas are taller $(137 \mathrm{~cm}-330 \mathrm{~cm})$, leaves grow faster with more young reddish leaves than those planted in shaded places $(86 \mathrm{~cm}-165 \mathrm{~cm})$ (Figure 3G). After 365 days, most of the leaves were found at the upper part of the stem and syconia start to develop at the axil of each leaf (Figure $3 \mathrm{H})$.

Seed germination is the most vulnerable process in the development of Ficus. Similar to F. virens, the germination and development of F. pseudopalma is positively photoblastic [13].

\section{Morpho-anatomy and development of syconium}

After 2 months of outplanting from the green house condition, syconia start to develop in pairs at the axils of the leaf (Figure 1J). A longitudinal section of the 3-day old syconium until the $30^{\text {th }}$ day revealed the following development as shown 


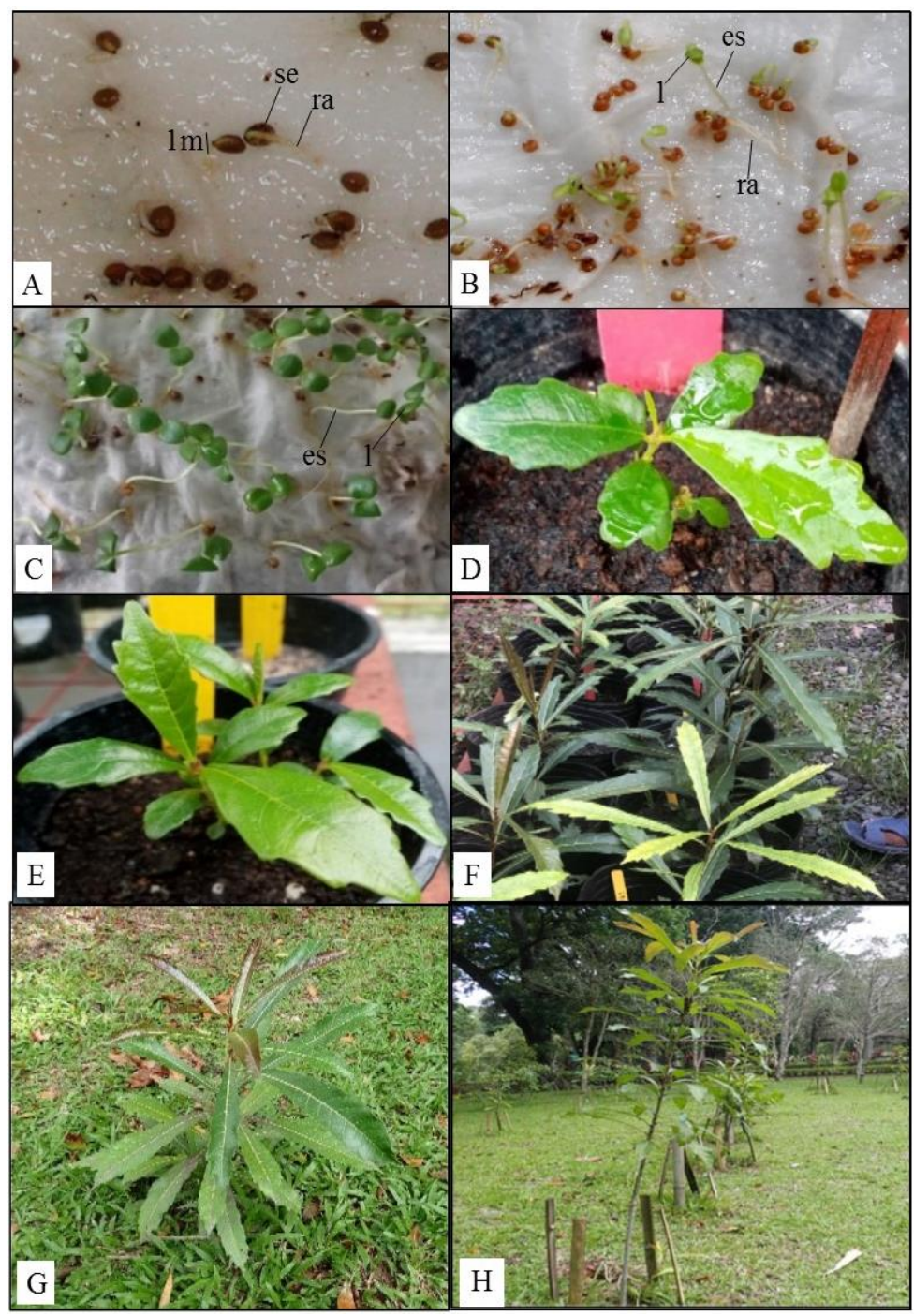

Figure 3. Development of F. pseudopalma. A. Germination after 4 days of sowing in petri dish with wet tissue paper showing seeds (se) and radicle (ra), B. Embryonic stem (es) and leaves (l) emerging from seed after 7 days of sowing, C. A more developed rounded leaves after 14 days of sowing, D. Bigger undulate leaves developed after 71 days of seed germination, E. Well-developed dentate leaves after 78 days, F. Healthy transplanted plants after 124 days, G. Young reddish leaves produced after 235 days, $\mathrm{H}$. Taller plants producing syconia after 365 days

in Figure 4.

a. tubercle stage: after three days, the distinct pistillate (p) and staminate (s) flowers completely compressed;

b. inverted bell-shape stage: after six days, the distal part of the receptacle (r) starts to flatten and ostiolar bracts (ob) expands a little upward, staminate flower differentiate with long filaments and anther near the ostiole (o) forming a U-shaped structure downward of the receptacle (r) while the pistillate (p) flowers are still undeveloped without pronounced pedicel and style forming a U-shaped structure configuration and whitish in color;

c. 2-eye stage: after nine days, ostiolar bracts (ob) form a hollow cavity formed below the inflexed ostiolar bracts and within the receptacle with well-developed staminate (s) flowers while some pistillate (p) flowers start to form styles;

d. club-shaped stage: after 12 days, the violet colored staminate (s) flowers are raised upward and horizontally aligned nearest the ostiole (o) while the whitish style elongate and becoming distinct with visible ovaries. At this stage a hollow cavity is formed at the center of the syconium while the ostiole (o) becomes narrow;

e. urn-shaped/urceolate stage: after 15 days, the 


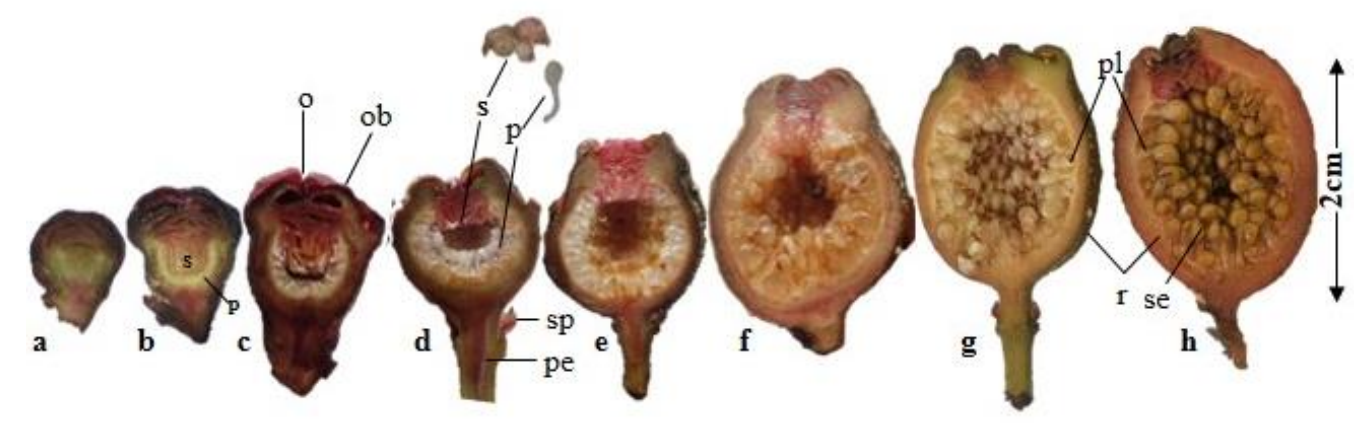

Figure 4. Longitudinal sections of the syconia arranged from the youngest to mature stage. Shows the development of staminate (s) and pistillate (p) flowers, osteolar bracts (ob), ostiole (o), sepals (sp), peduncle (pe), pedicel (pl), receptacle (r) and seeds (s).

mature staminate (s) flowers are arranged horizontally intertwining each other while the pistillate (p) flowers lost some of its styles and ovaries enlarging indicating pollination and fertilization has occurred as evidenced by the presence of wasp larvae.

f. pear-shaped stage: after 18 days the staminate (s) flowers degenerate, rotting and watery including seeds inside the receptacle (r), radicle formation starts with seeds enlarging with soft tissues in between originating from unfertilized ovules of the pistillate flowers. At this stage some of the larva developed into pupa;

g. oblong stage: after 21 days, staminate (s) flowers reduced in size occupying the apical part of the syconium while the ovaries occupy almost the entire with longer pedicels and most of the larvae hatched into pupa; and

h. ovate shape: after 30 days, seeds (se) are fully formed with long pedicels (pl) and most of the pupa hatched as adult wasp (Figure 4).

The full development of syconium F. pseudopalma is shorter than other Ficus species. It was studied that the time required for the completion of syconium development of $F$. petiolaris Kunth ranged from 91 to 126 days [15]. They also observed that the external morphology of the syconia of $F$. prctiolsris, such as its color, ostiole size and thickness of syconium wall, also changes through maturity.

\section{Pollination and Seed Formation}

After four (4) months of planting F. pseudopalma, it forms a pear-shaped structure called syconium, a specialized inflorescence enclosing the separate male and female flowers. Syconia occur in pairs at the axils of the leaves, covered with hairs when young and disappearing upon maturity, having white lenticels interspersed with dark warts. The syconium originates from the receptacle of multiple flowers. The male flowers are arranged near the small opening (ostiole) at the upper end of the syconium, and the female flowers are much more numerous at the interior part (Figure 4).

The female flowers are of two types: the longstyled fertile flowers and the short-styled sterile flowers (Figure 4d). When the sperm from the male flower fertilizes the egg of a long-styled female, it becomes the seed inside the single, small, one seeded hard-shelled fruit called achene. On the other hand, the short-styled sterile female flowers "gall flowers" become a mass of pulpy abnormal plant tissue (Figure 4f-h), on which the wasp larvae feed, and which they develop. It has been reported that the mutualistic gall wasps which pollinate the fertile flowers belong to the genus Blastophaga [16]. Each species of Ficus has an associated species of agaonid wasp (Hymenoptera: Chalcoidea: Agaonidae). Ficus species can only be pollinated by their associated agaonid wasps and in turn, the wasps can only lay eggs within their associated Ficus fruit [3].

The fig wasps enter the young syconia and lay the eggs in "gall flowers" (Figure 4). In about a month, the new wasps hatch out and emerges from the male flowers having pollen grains throughout the body surfaces and fertilizes the egg in the ovule to become the seed. On the other hand, male and female pollinators (Pegoscapus sp.) and parasitic wasp (Idarnes sp.) were observed pollinating the $F$. petiolaris syconia [15].

\section{Distribution and ecology}

F. pseudopalma is endemic to the Philippine 
and widely distributed in the forest from low altitude up to 430 masl. and luxuriantly growing in ultramafic soil. This species was reported to be present only in Luzon and growing at altitudes up to 1300 masl [1].

However, we have documented the species in several places of Mindanao such as Mt. Hamiguitan in Davao Oriental Province, Mt. Agad-Agad in Iligan City, Lanao del Norte and Mt. Malimumu in San Fernando, Bukidnon. Plants in exposed places are taller, reaching the height of $232 \mathrm{~cm}$ compared to plants in the shaded part of the forest.

\section{Conclusion}

The morpho-anatomical features of F. pseudopalma exhibited unique features such as the predominantly unbranched stem with distinct leaf scars, semi-amplexicaul stipules and spirally-arranged leaves crowded at the apical stem. The leaves have a normocytic stoma and an abundance of cystoliths without glandular trichomes. The stele is ectophloic siphonostele in the stem and transformed as dictyostele with leptocentric bundles in the leaf's petiole. Another insight is the development of the flowers, which remain entirely enclosed in a syconium. It takes 250-265 days to develop syconia from seed germination. The staminate flowers mature first and are restricted at the osteolar portion of the syconium while the pistillate flowers develop later and situated at the posterior side of the syconium just below the staminate flowers. The wasps fertilize Long-styled pistillate flowers while the short-styled staminate flowers degenerate and become soft and utilized as food by the larva of wasps. The syconia will mature in more or less 30 days. These morpho-anatomical features and development of $F$. pseudopalma have added botanical information regarding this endemic and economically important species.

\section{Acknowledgment}

This research was funded by the Philippine Department of Agriculture-Bureau of Agricultural Research. The logistic support of the Central Mindanao University in Maramag, Bukidnon, Philippines led by the University President, Dr. Jesus Antonio G. Derije and assistance of Daryl Bordios in collecting the specimens are gratefully acknowledged.

\section{References}

1. Berg CC, Corner EJH (2005) Moraceae (Ficus). In Flora Malesiana. Edited by H.P. Nooteboom. National Herbarium Nederland, Leiden, the Netherlands 17: 1 - 70. doi: $10.2307 / 25065564$.

2. Clement WL, Weiblen GD (2009) Morphological evolution in the mulberry family (Moraceae). Systematic Botany 34: $530 \quad-552$. doi: doi: 10.1600/036364409789271155.

3. Starr F, Starr K, Loope L (2003) Ficus pseudopalma Philippine Fig Moraceae. United States Geological SurveyBiological Resources Division. http://www.hear.org/starr/hiplants/reports/pdf/ficus_pseudopalma.pdf. Accessed date: March 10, 2021.

4. Santiago LA, Arimado JB, Mayor AB (2014) Ethnobotanical survey and nutritional composition of Ficus pseudopalma Blanco (Moraceae). Philippine Science Letters 7 (2): 401 - 505.

5. Stuart G (2008) An illustrated compilation of Philippine medicinal plants. doi: 10.13140/RG.2.2.11918.36160.

6. Sirisha N, Sreenivasulu M, Sangeeta K, Madhusudhana C (2010) Antioxidant properties of Ficus species - a review. International Journal of PharmTech Research 2 (4): 2174 - 2182.

7. Ragasa CP, Tsai P, Shen C (2009) Terpenoids and Sterols from the endemic and endangered Philippine trees, Ficus pseudopalma and Ficus ulmifolia. Philippine Journal of Science 138 (2): 205 - 209.

8. Bueno PR, Buno CBM, Santiago DLM, Santiago LA (2013) Antioxidant activity of Ficus pseudopalma Blanco and its cytotoxic effect on hepatocellular carcinoma and peripheral blood mononuclear cells. Current Research in Biological and Pharmaceutical Science 2 (2): 14 - 21.

9. Santiago LA, Valerio VL (2013) Assessment of antioxidant activities of crude ethanolic leaf extracts of $F$. pseudopalma Blanco (Moraceae). International Journal Pharmaceutical Frontier Research 3 (1): 15 - 21.

10. Yu Fan K, Bain A, Yu Tzeng H, Peng Chiang Y et al. (2019) Comparative anatomy of the fig wall (Ficus, Moraceae). Botany 97: 417 - 426. doi:10.1139/cjb-20180192.

11. Bailey LH, Bailey EZ (1976) Hortus. 3rd Edition. Macmillan General Reference, New York 1290.

12. Bercu R, Popoviciu DR (2014) Anatomical study of Ficus carica L. leaf. The Romanian Society for Cell Biology 19 (1): 33 - 36. doi:10.ANN/RSCB-2014-0002:RSCB.

13. Ji M, Qin H, Chen H, Wen B (2018) Seed germination requirements of Ficus virens (Moraceae) as adaptation to its hemi-epiphyte life form. Polish Journal of Ecology 66 (1): 14 - 22. doi: 10.3161/15052249PJE2018.66.1.002.

14. Ingle SY, Kothale KV (2018) Petioler Anatomy of Some Species of Ficus (Moraceae). International Journal of Science and Research (IJSR) 8 (11): 988 - 990. doi: 10.21275/ART20202801.

15. Piedra-Malagón E, Ramos B, Monterrosas AM et al. (2019) Syconium development in Ficus petiolaris (Ficus, sect. Americanae Moraceae) and the relationship with pollinator and parasitic wasps. Botany 97: 3. doi:10.1139/cjb-2018-0095.

16. Sinha KK (2003) Figs. Encyclopedia of Food Sciences and Nutrition 2394 - 239. doi:10.1016/B0-12-227055$\mathrm{X} / 00463-6$. 
This page is intentionally left blank. 